\title{
Diallel crosses among maize lines with emphasis on resistance to foliar diseases
}

\author{
Maria Elisa Ayres Guidetti Zagatto Paterniani ${ }^{1}$,Eduardo Sawazaki ${ }^{1}$, Christina Dudienas ${ }^{2}$, \\ Aildson Pereira Duarte ${ }^{3}$ and Paulo Boller Gallo ${ }^{4}$
}

\begin{abstract}
Ten elite maize (Zea mays L.) lines were crossed in a complete diallel scheme and the single-cross hybrids obtained were assessed at four experimental stations of the Agronomic Institute of Campinas, in São Paulo State, Brazil. The experiments were set up in a randomized complete block design with three replications, including four commercial checks. The experimental plots consisted of two 5-m rows spaced at $0.9 \mathrm{~m}$, with a total of 50 plants. The traits assessed included: days to mid-tassel pollen shed (DPS), plant height (PH), ear height (EH), grain yield, corrected for a 50-plant stand and 14\% moisture (GY corr.), and resistance to Phaeosphaeria maydis and Puccinia polysora. General and specific combining ability effects (GCA and SCA) were determined. There was extensive genetic variability among hybrids with the best hybrids (HS 04 x 10 and HS $10 \times 11$ ) not differing from the commercial checks. The lines with the greatest potential for hybrid synthesis included: L 10, L 11 and L 13, because they had higher GCA for yield, moderate resistance to $P$. maydis and reduced EH. The greatest contribution to reduction of the Phaeosphaeria stain was obtained with L 5. The magnitude of the GCA relative to the total variation indicated that additive effects predominated for resistance to $P$. maydis and $P$. polysora. Significant SCA (P $<0.01$ ) was also found, indicating dominance effects as well.
\end{abstract}

\section{INTRODUCTION}

The high incidence of leaf disease in maize crops in some areas of south central Brazil has led breeders to develop cultivars resistant to the main pathogens involved. The maize germplasm shows great variability, but little is known about its potential as a source of resistance to many diseases. In addition, little has been published on the inheritance or genetic potential of maize disease resistance, except for downy mildew caused by Peronosclerospora sorghi (Lima et al., 1982), northern corn leaf blight caused by Exserohilum turcicum (Narro León, 1996) and southern corn rust caused by Puccina polysora (Fantin et al., 1993).

Lima et al. (1996) have studied different maize lines and populations to identify the sources of resistance to several leaf diseases. Field assessments of commercial material have been done to examine the adaptation and tolerance to diseases in different edaphoclimatic regions in São Paulo State (Sawazaki et al., 1997; Duarte and Paterniani, 1997).

Heterosis has been used in maize breeding since Shull (1909) described the concept of single-cross hybrids. The development of new hybrids depends on the combining ability of the lines involved in the production of these hybrids.

The assessment of genetic variation of lines proposed by Griffing (1956) is based on the concepts of general (GCA) and specific (SCA) combining abilities established by Sprague and Tatum (1942), who presented detailed methods for analyzing fixed sets of lines or varieties in diallel crosses. Gardner and Eberhart (1966) suggested a model for analyses of fixed variety sets, in which the mean of an intervarietal hybrid is determined by the value of the varieties per se and by heterosis and its components.

Ten elite maize lines were crossed in a complete diallel design to estimate the general and specific combining abilities and the respective yield and resistance to two leaf diseases, caused by Phaeosphaeria maydis and Puccinia polysora, of the single-cross hybrids.

\section{MATERIAL AND METHODS}

Ten elite maize lines from CIMMYT (Centro Internacional de Mejoramiento de Maíz y Trigo) showing a high yield potential and satisfactory leaf disease resistance levels were selected and crossed in a 10 x 10-diallel scheme. The resulting 45 single-cross hybrids were assessed at four experimental stations of the Agronomic Institute of Campinas, in Campinas, Ribeirão Preto, Mococa and Assis. The experimental set up was a randomized complete-block design with three replications. The commercial hybrids AG 5011, C 333, P 3041 and Z 8392 were used as controls. Each plot consisted of two 5-m rows spaced at 0.9 $\mathrm{m}$ between rows, with a total of 50 plants. The following agronomic traits were assessed: days to mid-tassel pollen shed (DPS), plant height (PH) and ear height (EH) in five

\footnotetext{
${ }^{I}$ Centro de Plantas Graníferas, Instituto Agronômico de Campinas (IAC), Av. Barão de Itapura, 1481, Caixa Postal 28, 13001-970 Campinas, SP, Brasil. Send correspondence to M.E.A.G.Z.P. E-mail: elisa@cec.iac.br ${ }^{2}$ Centro de Fitossanidade, IAC, Campinas, SP, Brasil. 
Table I - Means for days (d) to mid-tassel pollen shed (DPS), plant height (PH), ear height (EH), grain yield (GY corr.) in kg/ha corrected for $14 \%$ moisture and ideal stand, and disease severity scores for 45 single-cross maize hybrids of a 10 x 10 diallel evaluated at four locations in São Paulo State.

\begin{tabular}{|c|c|c|c|c|c|c|c|}
\hline Hybrids & $\begin{array}{l}\text { Treat. } \\
\text { (No.) }\end{array}$ & $\begin{array}{l}\text { DPS } \\
\text { (d) }{ }^{1}\end{array}$ & $\begin{array}{l}\mathrm{PH} \\
(\mathrm{m})\end{array}$ & $\begin{array}{l}\mathrm{EH} \\
(\mathrm{m})\end{array}$ & $\begin{array}{l}\text { GY corr. } \\
(\mathrm{kg} / \mathrm{ha})\end{array}$ & $\begin{array}{c}\text { Phaeosphaeria } \\
\text { maydis }^{2}\end{array}$ & $\begin{array}{l}\text { Puccinia } \\
\text { polysora }^{2}\end{array}$ \\
\hline $\mathrm{HS} 02 \times 03$ & 1 & 61 & 2.01 & 1.06 & 5,954 & 5.5 & 4.2 \\
\hline HS $02 \times 04$ & 2 & 62 & 2.02 & 1.02 & 6,408 & 4.0 & 3.6 \\
\hline HS $02 \times 05$ & 3 & 62 & 2.09 & 1.15 & 6,833 & 2.6 & 2.4 \\
\hline HS $02 \times 06$ & 4 & 60 & 2.07 & 1.14 & 7,328 & 3.2 & 2.3 \\
\hline $\mathrm{HS} 02 \times 08$ & 5 & 64 & 1.90 & 1.03 & 5,710 & 3.2 & 2.2 \\
\hline HS $02 \times 09$ & 6 & 60 & 2.50 & 1.10 & 6,633 & 4.9 & 2.6 \\
\hline HS $02 \times 10$ & 7 & 62 & 2.00 & 1.02 & 7,715 & 3.8 & 2.8 \\
\hline HS $02 \times 11$ & 8 & 64 & 2.06 & 1.09 & 7,002 & 4.2 & 2.5 \\
\hline $\mathrm{HS} 02 \times 13$ & 9 & 62 & 2.06 & 1.04 & 7,057 & 4.2 & 2.9 \\
\hline HS $03 \times 04$ & 10 & 65 & 1.72 & 0.93 & 3,553 & 6.2 & 4.8 \\
\hline HS $03 \times 05$ & 11 & 64 & 2.05 & 1.11 & 6,178 & 2.3 & 4.0 \\
\hline HS $03 \times 06$ & 12 & 63 & 2.04 & 1.14 & 7,233 & 4.0 & 3.5 \\
\hline HS $03 \times 08$ & 13 & 64 & 2.01 & 1.13 & 7,266 & 5.5 & 3.0 \\
\hline HS $03 \times 09$ & 14 & 62 & 1.87 & 1.04 & 6,921 & 5.9 & 3.1 \\
\hline HS $03 \times 10$ & 15 & 62 & 2.03 & 1.04 & 8,232 & 4.8 & 3.4 \\
\hline HS $03 \times 11$ & 16 & 62 & 2.03 & 1.09 & 7,818 & 4.9 & 2.9 \\
\hline HS $03 \times 13$ & 17 & 60 & 1.99 & 1.02 & 7,547 & 4.3 & 2.2 \\
\hline HS $04 \times 05$ & 18 & 63 & 2.17 & 1.10 & 7,006 & 2.5 & 3.4 \\
\hline HS 04 x 06 & 19 & 62 & 2.04 & 1.05 & 7,665 & 3.1 & 3.6 \\
\hline HS 04 x 08 & 20 & 62 & 2.02 & 1.06 & 8,059 & 5.0 & 2.8 \\
\hline HS $04 \times 09$ & 21 & 62 & 1.97 & 1.04 & 7,686 & 5.0 & 3.4 \\
\hline HS $04 \times 10$ & 22 & 61 & 1.99 & 0.98 & 8,992 & 4.5 & 3.1 \\
\hline HS $04 \times 11$ & 23 & 62 & 2.06 & 0.98 & 7,951 & 4.0 & 3.5 \\
\hline HS $04 \times 13$ & 24 & 62 & 2.00 & 1.05 & 7,441 & 4.1 & 3.6 \\
\hline HS $05 \times 06$ & 25 & 62 & 2.02 & 1.10 & 5,315 & 3.4 & 2.8 \\
\hline HS $05 \times 08$ & 26 & 62 & 2.03 & 1.07 & 6,796 & 2.6 & 2.3 \\
\hline HS $05 \times 09$ & 27 & 60 & 1.99 & 1.07 & 7,508 & 2.9 & 2.4 \\
\hline HS $05 \times 10$ & 28 & 60 & 2.06 & 1.08 & 7,448 & 2.5 & 2.5 \\
\hline HS $05 \times 11$ & 29 & 61 & 2.11 & 0.99 & 7,419 & 2.3 & 2.1 \\
\hline HS $05 \times 13$ & 30 & 59 & 1.99 & 1.04 & 7,286 & 2.6 & 2.4 \\
\hline HS $06 \times 08$ & 31 & 62 & 2.12 & 1.13 & 6,809 & 3.3 & 2.4 \\
\hline HS $06 \times 09$ & 32 & 61 & 1.89 & 1.04 & 7,474 & 3.6 & 3.3 \\
\hline HS $06 \times 10$ & 33 & 59 & 1.99 & 1.10 & 8,350 & 3.2 & 2.3 \\
\hline HS $06 \times 11$ & 34 & 62 & 2.02 & 1.04 & 7,734 & 3.1 & 2.4 \\
\hline HS $06 \times 13$ & 35 & 60 & 2.09 & 1.13 & 7,759 & 3.0 & 2.4 \\
\hline HS $08 \times 09$ & 36 & 60 & 1.88 & 1.00 & 7,133 & 4.9 & 2.3 \\
\hline HS $08 \times 10$ & 37 & 60 & 1.94 & 1.00 & 8,282 & 3.7 & 2.2 \\
\hline HS $08 \times 11$ & 38 & 60 & 1.94 & 0.89 & 6,867 & 3.8 & 2.3 \\
\hline HS $08 \times 13$ & 39 & 60 & 1.90 & 0.98 & 7,370 & 3.8 & 2.1 \\
\hline HS $09 \times 10$ & 40 & 60 & 1.61 & 0.81 & 5,404 & 4.3 & 2.8 \\
\hline HS $09 \times 11$ & 41 & 60 & 1.95 & 1.02 & 8,253 & 4.1 & 2.2 \\
\hline $\operatorname{HS} 09 \times 13$ & 42 & 60 & 1.88 & 0.93 & 8,003 & 5.0 & 2.6 \\
\hline HS $10 \times 11$ & 43 & 62 & 1.96 & 0.98 & 8,899 & 3.3 & 2.7 \\
\hline HS $10 \times 13$ & 44 & 59 & 1.89 & 0.89 & 8,253 & 3.8 & 2.4 \\
\hline HS $11 \times 13$ & 45 & 59 & 1.96 & 0.93 & 7,944 & 3.0 & 2.1 \\
\hline AG5011 3 & 46 & 64 & 1.97 & 0.92 & 9,225 & 2.1 & 2.0 \\
\hline C $333^{3}$ & 47 & 64 & 1.80 & 0.96 & 9,637 & 2.8 & 3.3 \\
\hline $\mathrm{P} 3041^{3}$ & 48 & 63 & 2.09 & 1.07 & 9,757 & 2.8 & 2.6 \\
\hline $\mathrm{Z} 8392^{3}$ & 49 & 60 & 1.91 & 0.88 & 8,867 & 3.7 & 2.0 \\
\hline Mean & & 61.5 & 1.98 & 1.03 & 7,255 & 3.8 & 2.8 \\
\hline $\mathrm{CV} \%$ & & 4.8 & 8.0 & 9.8 & 9.4 & 7.4 & 6.5 \\
\hline LSD (Tukey test 0.05 ) & & - & 0.18 & 0.15 & 1,122 & 1.2 & 1.4 \\
\hline
\end{tabular}

${ }^{1}$ Days after sowing. ${ }^{2}$ Scale of 1 to $9 .{ }^{3}$ Checks. 
competitive plants in each plot, grain yield (GY corr.), corrected for a 50-plant stand and $14 \%$ grain moisture, and resistance to $P$. maydis and P. polysora. The presence of leaf diseases was assessed about 30 days after flowering, on a scale of 1 to 9 , for $0,1,10,20,30,40,60,80$, and $>80 \%$ of the leaf area affected in the adult plant, respectively. The average severity scores were transformed via $\sqrt{ }(x+1)$.

Preliminary analyses of variance procedure for a randomized complete-block design were performed for all the traits in the hybrids study, and the means were compared by the Tukey test. Entry mean effects and their corresponding location interactions were further subdivided into GCA and SCA effects using Griffing's Method 4, Model 1, diallel analysis (Griffing, 1956).

The Genes Program (Cruz, 1997) was used for statistical and genetic analyses.

\section{RESULTS AND DISCUSSION}

Analysis of variance indicated significant differences $(\mathrm{P}<0.01)$ among the hybrids for all the traits assessed (Table I). The best single-cross hybrid did not differ significantly from the mean of the commercial control hybrids (Table II). Hybrids HS $04 \times 10$ and HS $10 \times 11$ had the best performance at all locations in spite of large edaphoclimatic differences, which confirms the wide adaptability of these genotypes.

Phaeosphaeria maydis was more prevalent in Mococa, Assis, and Ribeirão Preto, where it was possible to discriminate hybrids according to their genetic resistance (scores of 2.1 to 6.2). There was a lower incidence of $P$. polysora in Assis and Ribeirão Preto (scores of 2.1 to 4.6). Hybrids with L 5 as one of the parents had scores of resistance to $P$. maydis between 2.0 and 3.0, which was confirmed in the diallel analysis of combining ability $\left(\mathrm{g}_{4}=-1.48\right)$ (Table III).

The sources of location variation $(\mathrm{L})$, hybrids $(\mathrm{H})$ and the $\mathrm{H} x \mathrm{~L}$ interaction were highly significant $(\mathrm{P}<0.01)$ (Table IV), indicating the great diversity among the singlecross hybrids and relatively differential behavior in the different environments. Similar results were obtained by Gama et al. (1995), which confirms the idea that singlecross hybrids with a narrow genetic base have a greater $\mathrm{H} \times \mathrm{L}$ interaction than populations from a wider genetic base (Sprague and Eberhart, 1977).

Joint analyses of the GCA and SCA effects (Griffing, 1956) were highly significant for all the traits (Table IV). Plant and ear height mean squares for SCA were much lower than for GCA, indicating that additive effects were more important in the control of these characteristics. The variation among the GCA effects contributed $70 \%$ of the total variation for grain yield, while $30 \%$ was accounted for by SCA effects, indicating significant non-additive effects (Table IV). According to Hallauer and Miranda Filho (1988), dominance effects are more important for grain yield than for plant and ear height.
Table II - Mean grain yield corrected for single-cross maize hybrids obtained from a 10 x 10 diallel, the best single-cross hybrid, the commercial controls, least significant differences (LSD) at the 0.05 probability level (Tukey test) and coefficient of variation (CV\%) for experiments at four locations in São Paulo State.

\begin{tabular}{|llc|}
\hline Location & Hybrids & $\begin{array}{c}\text { Grain yield corr. } \\
\text { (kg/ha) }\end{array}$ \\
\hline Campinas & Single-cross hybrid mean & 8,311 \\
& Best single-cross hybrid & 10,375 \\
& Control mean & 10,060 \\
& LSD (Tukey test, 0.05) & 1,951 \\
Mococa & CV\% & 7.2 \\
& Single-cross hybrid mean & 7,785 \\
& Best single-cross hybrid & 9,362 \\
& Control mean & 9,091 \\
& LSD (Tukey test, 0.05) & 2,144 \\
& CV\% & 8.1 \\
& Single-cross hybrid mean & 7,112 \\
& Best single-cross hybrid & 8,976 \\
& Control mean & 9,986 \\
& LSD (Tukey test, 0.05) & 3,010 \\
& CV\% & 12.5 \\
Ribeirão Preto & Single-cross hybrid mean & 5,814 \\
& Best single-cross hybrid & 7,326 \\
& Control mean & 8,372 \\
& LSD (Tukey test, 0.05) & 2,128 \\
& CV\% & 11.1 \\
Combined & Single-cross hybrid mean & 7,255 \\
& Best single-cross hybrid & 8,899 \\
& Control mean & 9,372 \\
& LSD (Tukey test, 0.05) & 1,122 \\
& CV\% & 9.4 \\
\hline
\end{tabular}

Table III - General combining ability estimates $\left(\mathrm{g}_{\mathrm{i}}\right)$ for 10 maize lines and the range of the specific combining ability $\left(\mathrm{s}_{\mathrm{ij}}\right)$ for plant height $(\mathrm{PH})$, ear height (EH), grain yield corrected (GY corr.), and severity scores for Phaeosphaeria maydis and Puccinia polysora.

\begin{tabular}{|rcrrrcc|}
\hline Lines & $\mathrm{g}_{\mathrm{i}}$ & $\begin{array}{c}\text { PH } \\
(\mathrm{m})\end{array}$ & $\begin{array}{c}\text { EH } \\
(\mathrm{m})\end{array}$ & $\begin{array}{c}\text { GY corr. } \\
\text { (kg/ha) }\end{array}$ & $\begin{array}{c}\text { P. maydis } \\
\text { (1 to 9) }\end{array}$ & $\begin{array}{c}\text { P. polysora } \\
\text { (1 to 9) }\end{array}$ \\
\hline L2 & 01 & 0.048 & 0.040 & -582 & 0.09 & 0.15 \\
L3 & 02 & -0.015 & 0.029 & -575 & 1.13 & 1.73 \\
L4 & 03 & 0.010 & -0.016 & -67 & 0.47 & 1.40 \\
L5 & 04 & 0.075 & 0.049 & -439 & -1.48 & -0.43 \\
L6 & 05 & 0.047 & 0.068 & 46 & -0.64 & -0.35 \\
L8 & 06 & -0.012 & -0.006 & -125 & 0.16 & -0.68 \\
L9 & 07 & -0.101 & -0.036 & -35 & 0.70 & -0.18 \\
L10 & 08 & -0.056 & -0.052 & 784 & -0.14 & -0.52 \\
L11 & 09 & 0.022 & -0.041 & 574 & -0.16 & -0.64 \\
L 13 & 10 & -0.018 & -0.037 & 420 & -0.09 & -0.48 \\
$\mathrm{~S}_{\mathrm{ij}}$ & $\leftarrow$ & -0.264 & -0.139 & -3060 & -1.25 & -1.98 \\
& $\rightarrow$ & 0.116 & 0.065 & 1019 & 1.57 & 0.94 \\
\hline
\end{tabular}

The GCA $x$ location interaction was highly significant $(\mathrm{P}<0.01)$ and greater than the SCA $x$ location interaction $(\mathrm{P}<0.05)$ (Table IV), which agrees with the studies of Matzinger et al. (1959) and Gama et al. (1995). The presence of a significant GCA effect $x$ location interaction suggests a need to select different parent lines for hybrid production at different locations.

The GCA effects for leaf disease severity scores 
Table IV - Mean squares of the analysis of variance of plant height (PH), ear height (EH), grain yield corr. (GY corr.), and severity scores for Phaeosphaeria maydis (Pm) and Puccinia polysora $(P p)$ in 45 maize single-cross hybrids.

\begin{tabular}{|lrrrllrrr|}
\hline $\begin{array}{l}\text { Source of } \\
\text { variation }\end{array}$ & d.f. & $\begin{array}{c}\text { GY corr. } \\
\text { (kg/ha) }\end{array}$ & d.f. & $\begin{array}{l}\text { PH } \\
\text { (m) }\end{array}$ & $\begin{array}{l}\text { EH } \\
\text { (m) }\end{array}$ & $\begin{array}{c}P m \\
(1 \text { to } 9)\end{array}$ & d.f. & $\begin{array}{c}P p \\
\text { (1 to } 9)\end{array}$ \\
\hline Hybrids (H) & 44 & $11.73^{* *}$ & 44 & $0.088^{* *}$ & $0.048^{* *}$ & $9.53^{* *}$ & 44 & $2.44^{* *}$ \\
GCA & 9 & $21.40^{* *}$ & 9 & $0.198^{* *}$ & $0.135^{* *}$ & $37.31^{* *}$ & 9 & $9.40^{* *}$ \\
SCA & 35 & $9.25^{* *}$ & 35 & $0.059^{* *}$ & $0.026^{* *}$ & $2.39^{* *}$ & 35 & $0.64^{*}$ \\
Location (L) & 3 & $157.14^{* *}$ & 2 & $1.913^{* *}$ & $0.836^{* *}$ & $217.7^{* *}$ & 1 & $9.12^{* *}$ \\
HxL & 132 & $0.82^{* *}$ & 88 & $0.016^{* *}$ & $0.013^{* *}$ & $1.17^{* *}$ & 44 & $2.46^{* *}$ \\
GCAxL & 27 & $1.49^{* *}$ & 18 & $0.021^{* *}$ & $0.016^{* *}$ & $3.47^{* *}$ & 9 & $9.47^{* *}$ \\
SCAxL & 105 & $0.64^{*}$ & 70 & $0.015^{* *}$ & $0.012^{* *}$ & $0.58^{* *}$ & 35 & $0.65^{* *}$ \\
Error & 352 & 0.49 & 264 & 0.0093 & 0.0072 & 0.39 & 176 & 0.38 \\
Mean & & 7,255 & & 1.99 & 1.04 & 3.47 & & 2.87 \\
\hline
\end{tabular}

*, **: Significant at the 0.01 and 0.05 probability levels, respectively. ${ }^{1} \mathrm{MS}$ multiplied by $10^{6}$.

accounted for about $94 \%$ of the total variation, indicating the predominantly additive nature of the inheritance of resistance to $P$. maydis and $P$. polysora. There were also dominance effects, as suggested by the significant SCA effects (Table IV). Studies by Fantin et al. (1993) on resistance to $P$. polysora demonstrated the additive nature of this response, because the mean square for additivity was ten times higher than the mean square for dominance; there was, however, a partial dominance effect for resistance.

GCA effects $\left(\mathrm{g}_{\mathrm{i}}\right)$ and the range of the SCA effects $\left(s_{i j}\right)$ (Table III) for plant and ear height and the corrected grain yield traits show that plant and ear height were reduced more in lines L 9 and L 10. Greater reductions in the $P$. maydis scores were obtained in L 5 and for $P$. polysora, in $\mathrm{L} 8$; thus, these lines are sources of resistance to these diseases. Greater GCA effects for GY corr. were associated with lines L 10 (784 kg/ha), L $11(574 \mathrm{~kg} / \mathrm{ha})$ and L $13(420 \mathrm{~kg} / \mathrm{ha})$, considered promising for single-cross hybrid development. The greatest SCA effects were obtained from lines L 4 and L $10\left(\mathrm{~s}_{4,10}=1,018 \mathrm{~kg} / \mathrm{ha}\right)$ and L4 and L8 ( $\left.\mathrm{s}_{4,8}=997 \mathrm{~kg} / \mathrm{ha}\right)$.

In conclusion, among the inbred lines evaluated the most promising ones are L10, L11 and L13, since besides high GCA for grain yield, they also showed moderate resistance to $P$. maydis, as well as lower ear height. Two superior hybrids HS 04 x 10 and HS 10 x 11 did not differ in grain yield when compared to commercial checks. Considering the magnitude of general combining effects, resistance to $P$. maydis might be due mainly to additive effects, including also effects of dominance (significant SCA).

\section{ACKNOWLEDGMENTS}

The authors thank FAPESP for the financial support of this project, for the technical training grant and agricultural technician Paulo Cezar Antunes for his help in the field experiments. Publication supported by FAPESP.

\section{RESUMO}

Cruzaram-se dez linhagens-elite de milho em esquema dialélico completo e os híbridos simples obtidos foram avaliados em quatro Núcleos Experimentais do Instituto Agronômico de Campinas, SP, Brasil. Os ensaios foram instalados sob delineamento de blocos casualizados com três repetições, incluindo quatro testemunhas comerciais. As parcelas consistiram em duas linhas de $5 \mathrm{~m}$ espaçadas por $0,90 \mathrm{~m}$, contendo 50 plantas. Avaliaramse os caracteres: dias para o florescimento masculino (DPS), altura da planta $(\mathrm{PH})$ e da espiga $(\mathrm{EH})$, produtividade de grãos corrigida para estande ideal de 50 plantas e $14 \%$ de umidade (GY corr.) e resistência a Phaeosphaeria maydis (Pm) e a Puccinia polysora $(P p)$. Estimaram-se os efeitos da capacidade geral e específica de combinação das linhagens. Houve grande variabilidade genética entre os híbridos, sendo que os melhores (HS 04 x 10 e HS 10 x 11) não diferiram das testemunhas comerciais. As linhagens de maior potencial para síntese de híbridos no conjunto em questão foram: L 10, L 11 e L 13, por aliarem alta GCA para produtividade, resistência moderada a $P$. maydis e redução da altura da espiga. A maior contribuição para redução da mancha de Phaeosphaeria foi proveniente de L 5. A magnitude da GCA em relação à variação total corroborou a natureza preponderantemente aditiva da resistência às doenças estudadas. A presença da SCA significativa ( $\mathrm{P}<0,01)$ foi também confirmada, indicando a existência de efeitos de dominância.

\section{REFERENCES}

Cruz, C.D. (1997). Programa Genes: Aplicativo computacional em Genética e Estatística. UFV, Viçosa.

Duarte, A.P. and Paterniani, M.E.A.G.Z. (1997). Cultivares de milho no Estado de São Paulo. Documentos IAC, 62. Instituto Agronômico, Campinas, pp. 81.

Fantin, G.M., Silva, H.P., Balmer, E. and Miranda Filho, J.B. (1993). Herança da resistência à ferrugem causada por Puccinia polysora em milho. Fitopatol. Bras. 18 (Suppl.): 332-333.

Gama,E.E.G., Hallauer, A.R.,Ferrão, R.G. and Barbosa, D.M. (1995). Heterosis in maize single crosses derived from a yellow Tuxpeño variety in Brazil. Rev. Bras. Genet. 18: 81-85.

Gardner, C.O. and Eberhart, S.A. (1966). Analysis and interpretation of the variety cross diallel and related populations. Biometrics 22: 439452.

Griffing, J.B. (1956). Concept of general and specific combining ability in 
relation to diallel systems. Austr. J. Biol. Sci. 9: 463-493.

Hallauer, A.R. and Miranda Filho, J.B. (1988). Quantitative Genetics in Maize Breeding. 2nd edn. Iowa State University Press, Ames.

Lima, M., Gimenes-Fernandes, N., Miranda Filho, J.B. and Pereira, J.C.V.A. (1982). Introduction of maize germplasms as sources for downy mildew resistance. Maydica 27: 159-168.

Lima, M., Paterniani, M.E.A.G.Z., Dudienas, C., Siqueira, W.J., Sawazaki, E. and De Sordi, G. (1996). Avaliação da resistência à ferrugem tropical em linhagens de milho. Bragantia 55: 269-273.

Matzinger, D.F., Sprague, G.F. and Cockerham, C.C. (1959). Diallel cross of maize in experiments repeated over locations and years. Agron. J. 51: 346-350.

Narro León, T.P. (1996). Parâmetros genéticos e fenotípicos de resistência a Exserohilum turcicum (Pass) Leonard Sugg em populações de milho.
Doctoral thesis, ESALQ/USP, Piracicaba, SP.

Sawazaki, E., Dudienas, C., Paterniani, M.E.A.G.Z., Galvão, J.C.C., Castro, J.L. and Pereira, J. (1997). Reação de cultivares de milho à mancha de Phaeosphaeria no Estado de São Paulo. Pesqui. Agropecu. Bras. 32: 585-589.

Shull, G.F. (1909). A pure line method of corn breeding. Am. Breed. Assoc. Rep. 5: 51-59.

Sprague, G.F. and Eberhart, S.A. (1977). Corn breeding. In: Corn and Corn Improvement (Sprage, G.F., ed.). American Society of Agronomy, Madison, WI, pp. 305-362.

Sprague, G.F. and Tatum, L.A. (1942). General vs. specific combining ability in single crosses of corn. Am. Soc. Agron. 34: 923-932.

(Received March 17, 1999) 
